\title{
Spontaneous Osteonecrosis of the Knee: a Systematic Review of Conservative Treatment Approaches
}

Johannes Lair ( $\square$ johanneslair@gmx.at)

NA

Christian Fink

Gelenkpunkt

Robert Csapo

UMIT - Private Universität für Gesundheitswissenschaften, Medizinische Informatik und Technik

\section{Research Article}

Keywords: Spontaneous osteonecrosis of the knee, SONK, SIFK, conservative, treatment, therapy

Posted Date: February 23rd, 2021

DOI: https://doi.org/10.21203/rs.3.rs-239294/v1

License: () (i) This work is licensed under a Creative Commons Attribution 4.0 International License. Read Full License 


\section{Abstract}

Background: Spontaneous osteonecrosis of the knee (SONK) is an insufficiently defined disease. Although recent research suggests that SONK may be caused by subchondral insufficiency fractures, its precise etiology remains unclear. Currently, no therapeutic guidelines exist.

Purpose: This systematic review aimed to collate the scientific literature on conservative treatment approaches for SONK and to derive respective recommendations.

Methods: The PUBMED database was searched for relevant articles published until November 2020. All articles in German or English language dealing with the conservative therapy of SONK were included. Animal research studies and reviews were not considered. Studies that used specific treatment outcomes as inclusion criterion and those that lacked a conservative treatment group, magnetic resonance imaging-based diagnosis, reported outcomes of conservatively managed patients or basic descriptions of the treatment modalities were excluded.

Results: Twenty-two articles comprising a total sample size of 521 patients were included. Eighteen of the included studies (82\%) tested the effects of some form of restriction of weight-bearing, bisphosphonates or a combination of both. Sixteen studies (73\%) reported clinical and/or radiological improvements. However, outcomes varied considerably in dependency of the radiologic presentation, demography and further prognostic factors.

Conclusion: Many conservative therapy methods appear effective in the treatment of orthopedic syndromes classified as SONK, with the most robust evidence existing for restriction of weight-bearing and bisphosphonates. The heterogeneity of radiologic presentations and treatment outcomes suggests that the generic term SONK might obscure the presence of different underlying pathologies. Indeed, many lesions may represent subchondral fractures, which should be referred to as subchondral fractures of the knee (SFK). A clear delineation of the disorders and standardized MRI-based diagnostic criteria are required.

\section{Background}

In 1968, spontaneous osteonecrosis of the knee (SONK) was first described by Ahlbäck et al. [1]. Initially, the condition manifests as suddenly occurring atraumatic knee pain, with a typically unilateral involvement of the medial femoral condyle (around 90\%) [2]. Females, particularly those aged 60 years or older, are affected three times more frequently than men [3,4]. Recent research supports the hypothesis that SONK occurs due to subchondral insufficiency fractures, which has led some authors to discount SONK as a misnomer and to propose to rename it as subchondral insufficiency fractures of the knee (SIFK) [5]. However, since the term SONK is still used as a common diagnosis, the etiology of the condition has not been fully clarified. In consequence, there is no consensus about the radiological appearance of the associated lesions, and the gold standard of therapy, which may rely on either surgical or conservative approaches, yet needs to be established. While the applicable surgical techniques are reasonably well documented [3,6], evidence regarding the indications, potentials and limitations of conservative treatment options is limited. The latter typically consists of restricted weight-bearing (RWB), combined with the administration of non-steroidal anti-inflammatory drugs (NSAID) and analgesics [6,7]. Studies regarding alternative concepts are rare and no evidence-based guidelines exist to advise clinicians about the proper application of these modalities. For this reason, this review aims to collate the scientific literature addressing different treatment modalities for the conservative management of SONK, to review their outcomes in dependency of the radiological presentation as well as the therapeutic approach used, in order to be able to give evidence-based treatment recommendations and facilitate decision making in clinical practice.

\section{Methods}

The structure of the study was related to the Preferred Reporting Items for Systematic Review and Meta-analysis (PRISMA) statement [8]. To capture all relevant articles published until November 2020, a systematic review of the PUBMED database was conducted twice, using the following search terms: $\{[($ Spontaneous OR idiopathic OR primary) AND (Necrosis OR osteonecrosis)] AND knee\} OR SONK OR SPONK OR Morbus Ahlbäck OR Ahlbäck disease. The abstracts of articles published in either English or German language were screened. Those dealing with the conservative management of SONK were included. Studies that used specific treatment outcomes as inclusion criterion and those that lacked a conservative treatment group, basic descriptions of the treatment modalities, outcomes reported for conservatively managed patients or magnetic resonance imaging (MRI)-based diagnosis, were excluded. Similarly, animal research studies and reviews were not considered. An MS Excelß-based spreadsheet was used to extract the following variables: study category, level of evidence, participant selection criteria, demographic data, anatomical region affected, stage, period of symptomatology until first visit, period until first magnetic resonance scan, radiological appearance in MRI, lesion size measured by MRI, treatment modality, treatment duration, follow-up period and radiological/clinical outcomes. Since the above variables were not consistently indicated in all studies, numbers and proportions given in the results section are always based on the studies in which they were reported. The quality of all included studies was assessed according to the Oxford Centre for Evidencebased Medicine (CEBM) - Levels of Evidence document [9]. The classification proposed by Koshino et al. [10] was chosen as universal staging system in this study. Where applicable, alternative disease classifications as those by Aglietti et al. [11] or Soucacos et al. [12] were converted into the Koshino staging system. Therapy recommendations were given based on the MRI data reported and assigned a grade of recommendation (GOR) according to the CEBM - Levels of Evidence document [9].

\section{Results}

The initial literature research revealed a total of 925 articles. All 829 articles written in English or German were subsequently screened, which resulted in 81 articles fulfilling the inclusion criteria. After a detailed review and application of the previously determined exclusion criteria, 22 articles were considered suitable for analysis. Figure 1 provides an overview of the process of literature research and selection. 
All included studies were published between the year 2000 and 2020 and consisted of 8 case series, 6 case reports, 4 cohort studies, 2 case control series, 1 interventional study and 1 randomized controlled trial with $<80 \%$ follow-up. The level of evidence ranged from level 5 to level $2 b$.

\section{Patient characteristics}

The included studies comprised 521 patients with a mean age of 61.2 years, of whom $332(63.7 \%)$ were female. The medial femoral condyle was affected in $70.6 \%$ of cases. The majority of lesions were in Koshino stage $1(67.6 \%)$ or $2(27.5 \%)$ whereas only $4.9 \%$ of cases were classified as stages 3 and 4 . The average duration of therapy and follow-up time were 4.3 months and 3.0 years, respectively. With an average of 7.2 months, drug therapies were used longer compared to other therapies (mean of 2.9 months). Detailed descriptions are shown in Tables 1-5.

\section{Therapies}

The following therapy concepts were used: RWB or even complete unloading by using crutches, bed rest, specifically designed shoes or shoe insoles, unloader braces, etc. $(n=11)$, bisphosphonates (alendronate/ibandronate) $(n=3)$, a combination of RWB (crutches/cane/walker) with the administration of bisphosphonates (alendronate/ibandronate/zoledronate) $(n=4)$, teriparatide $(n=1)$, laser-needle therapy $(n=1)$, pulsed electromagnetic fields (PEMF) therapy $(n=1)$ as well as a hyperbaric chamber combined with orally applied ibandronate and RWB $(n=1)$. In some studies, these therapies were complemented by secondary assistive treatment approaches, which included the administration of NSAID, vitamin D and/or calcium, injections of hyaluronan or corticosteroids and physiotherapy.

\section{Magnetic resonance imaging}

The MRI-based criteria used for the differential diagnosis of SONK were found to be heterogeneous. While some authors screened images for specific features, such as focal hypointense areas on T1- or T2-weighted images, visible fracture lines or focal epiphyseal contour depressions [7,13-24], others diagnosed SONK in the presence of bone marrow edema (BME) accompanying typical symptoms [25-27]. Two case reports radiologically demonstrated the primary overlay of fracture lines by BME [28,29]. Some studies failed to report the MRI criteria used for diagnosis [30-33]. In total, BME were observed in $92.9 \%$ of patients, whereas fractures were reported to be present in $44.7 \%$.

\section{Prognostic/risk factors}

In the included studies, the following parameters were found to negatively influence the course of the disease: age over 65 years [24], varus alignment [17,19,24], affection of the medial femoral condyle or medial tibial plateau [24], meniscal extrusion [24], end stage osteoarthritis [24] and larger defect size $[18,19]$. Decreased bone mineral density $[18,19]$ was associated with the onset of SONK, but not with its progression [17-19]. Obesity [17,24], sex [17,24] or the presence of BME were not associated with poorer prognosis. Contradictory findings were reported for age [17], meniscal extrusion [19] and lesion size $[7,17,27,31]$

\section{Therapy outcomes}

Sixteen of the twenty-two included studies (73\%) reported positive clinical and/or radiological outcomes [7,13,17,20-23,25-33]. Although RWB was the most thoroughly tested treatment modality, it has also been challenged by some authors. While four studies reported only moderate to poor results [14-16,24], nine observed favorable outcomes when testing one of the various forms of RWB [7,17,21,27,32] or a combination of RWB with bisphosphonates [20,25,29,33]. Treatment through bisphosphonates alone was positively evaluated in all studies $[23,30,31]$. The only controlled trial, however, found bisphosphonates not to yield superior outcomes as compared to placebos [23]. Furthermore, even though orally administered alendronate was the most often used bisphosphonate, the available data and the complexity of the individual therapies did neither allow to establish a superior bisphosphonate, nor the best mode of administration or treatment regimen. The administration of teriparatide [22], laser-needle therapy [13], PEMF therapy [26] and the usage of a hyperbaric chamber [28] were all successfully tested in single trials only.

Regarding different MRI differential diagnoses, it was found that especially lesions showing only BME responded excellently to conservative therapy measures, whereas treatment success was less clear in the presence of further MRI features (Table 6). The only frequently described MRI feature for which mainly moderate to poor results were reported, are focal low signal intensities on T1-weighted images [14,15,19,24]. Although a complete remission of pathologic MRI signals was reported 3 months after therapy initiation [7], most lesions persisted longer than 6 months despite radiologic signs of healing $[7,13,22,25,26,29-31]$. In this regard, Geijer et al. [29] reported the course of a lesion the healing of which took over 2.5 years. By contrast, clinical symptoms often improved significantly after 2 to 6 weeks $[13,21,22,25,29,30,33]$. A complete disappearance of symptoms was described at the earliest after 2 to 3 months of continuous therapy $[7,13,17]$. Longitudinal data, allowing for the development of the stage of SONK to be traced, were available for 88 knees. Out of the 82 lesions initially diagnosed at stage 1, 19 progressed to more advanced stages. While ten of these lesions progressed to stage 4 and required knee arthroplasty, nine knees had good clinical results. However, due to marked symptomatology or radiological progression, a total of 158 out of 521 patients (30.3\%) required surgery during follow-up.

\section{Discussion}


The primary goal of the present study was to review the scientific literature on treatment approaches for the conservative management of SONK. Our literature research yielded 22 articles of low-to-moderate scientific evidence level. Results were reported for a total of 521 patients, the vast majority of whom were diagnosed at an early stage of SONK ( $67.6 \%$ Koshino stage $1,27.5 \%$ stage 2$)$. The preponderance of studies (18/22) tested the effectiveness of some form of RWB and/or the administration of bisphosphonates. Sixteen studies reported a positive impact of conservative therapy. Nevertheless, a total of 158 patients $(30.3 \%)$ reportedly required secondary surgery. However, the comparison of studies was complicated not only by the heterogeneity of treatment approaches but also the nonuniform diagnostic criteria applied. To help differentiate early-stage SONK from other pathologies, Lecouvet et al. [34] established MRI characteristics, which are generally well-accepted but neither universally applied nor suitable to substantiate the diagnosis beyond reasonable doubt. In consequence, the described radiologic presentations differed strongly between studies, which suggests that the lack of a clear definition of SONK leads to the term being generically used to label potentially different underlying pathologies.

The radiological inclusion criteria used in the studies summarized in this review suggest that approximately $78 \%$ of patients suffered from fractures or their consequences whereas in about $16 \%$, SONK was defined solely by the presence of BME. Although, the preponderance of lesions were likely fractures, the differences in the demographics of the included samples suggest that the causal mechanisms provoking these fractures were likely not equal. In the literature, higher age [1], female sex [1,11], low bone mineral density [35], cartilage degeneration [36,37] and medial meniscus posterior root tears [5] have been reported as important risk factors promoting the development of SONK. It is therefore plausible to assume that SONK, which has most frequently been described in postmenopausal women, would often be caused by reduced bone mineral density leading to insufficiency fractures [18,35,38]. However, several studies reported cases of SONK in younger active males [7,13,27-29], in whom bone collapse might rather be provoked by non-osteoporotic fatigue fractures [29,38]. Since meniscal tears are often associated with SONK and can lead to increased tibiofemoral contact pressures [5], they may have a critical role in the development of both insufficiency and fatigue fractures. We, therefore, agree with Hussain and colleagues in that the current nomenclature should be revised [5]. However, due to the differences in demographics described above, we recommend that, in the presence of radiological evidence of fractures, lesions be classified as subchondral fractures of the knee (SFK) rather than as SIFK. Under certain conditions, SFK may progress to secondary osteonecrosis over time which, however, should also be clearly distinguished from SONK. In the future, it is imperative to further develop MRI-based or other diagnostic criteria that help better differentiate between transient BME, SFK, secondary osteonecrosis and eventually true cases of SONK.

\section{Treatment recommendations}

With the above-mentioned caveats in mind, this review reflects our efforts to evaluate the different conservative treatment approaches and grade the level to which they can be recommended. When considering conservative therapy options, it is important to take the patients' age [24] and limb alignment [17,19,24], the localization of the lesion [24], the state of meniscus and cartilage [24] as well as the size of the lesion [18,19] into account, as these are important prognostic factors. Table 6 summarizes the evidence supporting the use of different treatment options in dependency of the presentation of SONK in MRI. The grades of recommendation ranged from $D$ to $B$, as per the CEBM classification [9]. Especially treatment recommendations at GOR D should be viewed as preliminary, since they are based on the results of case reports only.

At present, conservative therapy should be considered primarily in Koshino stages 1 and 2, as insufficient evidence exists to support its use in later stages of the disease. With a mean therapy duration of 4.3 months (3.0 years mean follow-up), all forms of therapy must be sustained for prolonged periods, so patient compliance is crucial. Moreover, it is important to start therapies as early as possible, even before the precise nature of lesions can be clarified radiologically. This is because changes in MRI may take 6-10 weeks to manifest [39] and fractures may initially be obscured by pronounced BME [28,29]. Given the lack of studies comparing different treatment modalities, evidence-based ranking of their effectiveness is not possible. However, considering the most robust body of evidence in its support, it is recommended to start conservative therapy with RWB assisted by adequate pain management [7,17,20,21,25,27,29,32,33]. Authors, that reported good outcomes with RWB, treated their patients for a mean of 3.3 months $[7,20,21,25,27,29,32,33]$. In accordance with Bhatnagar et al. [25], we, therefore, recommend to use crutches initially for a minimum of 1.5 months. In order to minimize muscle atrophy, weight-bearing should be gradually resumed in a pain-adapted manner within the following 1.5 months, e.g., by replacing the crutches with a cane or some other walking aides. Supportive physiotherapy may also be used to avoid muscle deconditioning. Although one study found bisphosphonate therapy not to yield better outcomes than administration of a placebo [23], it should be prescribed as adjunctive therapy, especially in patients with possible insufficiency fractures. Since all the bisphosphonate regimens tested were found to be successful, no recommendation can be made regarding a superior administration form or a particular regimen. Nevertheless, considering the side effects, low-dose treatment is recommended [30]. Detailed descriptions of the therapies tested so far are shown in Tables 1-5.

\section{Study limitations}

The evidence level of most included studies was low and ranged between $2 b-5$. Sample sizes were typically small and treatment and follow-up periods short. Since this review focused exclusively on conservative therapy of SONK (and not similar conditions, such as SIFK or transient BME), the evidence regarding the treatment of individual MRI features is rather sparse. Ranking of therapies by their effectiveness was not possible due to the lack of studies directly comparing different approaches. The comparison of studies was further complicated by differences in demography, an incomplete documentation of prognostic data and MRI criteria as well as nonuniform staging systems, lesion size measurements and objective outcome measures. In several of the included studies, therapies were meagerly described. As an example, no information was provided on the devices used to restrict weight-bearing [7,14,15,19,21,27], or on the daily duration of use of specifically designed shoe insoles [17]. Furthermore, the presence of secondary osteonecrosis or osteonecrosis in the postoperative knee (ONPK) cannot always be excluded beyond doubt. It should also be noted that conservative treatment was considered as having failed if patients subsequently required surgery. This assumption may be simplistic, particularly when conservative treatment approaches were not fully exploited [18,19]. Ultimately, competing interests with manufacturers of the utilized devices [26,32], increase the risk of publication bias. 


\section{Conclusion}

The results of this systematic review of literature suggest that many lesions referred to as SONK may actually not occur spontaneously but rather represent subchondral fractures. We, therefore, agree with the recommendation of Hussain et al. [5] to revise the current nomenclature but recommend that, in the presence of radiological evidence of fractures, cases be referred to as subchondral fractures of the knee (SFK). Standardized MRI supported diagnostic criteria are required to differentiate between BME, SFK, secondary osteonecrosis and eventually true SONK. Lesions identified in the literature as early-stage SONK can often be successfully treated with one of the therapies mentioned in this review, taking into account their radiologic and clinical presentation. Therapy should be performed as early as possible, even in the case of radiologically unclear lesions. Patient compliance is crucial for treatment success. Based on the current evidence, we recommend to start conservative therapy with RWB. While weight-bearing should be avoided initially, it should be gradually resumed over the course of the therapy in a pain-adapted manner. Concomitant bisphosphonate therapy may be useful.

\section{Abbreviations}

BME: bone marrow edema

CEBM: Centre for Evidence-based Medicine

GOR: grade of recommendation

MRI: magnetic resonance imaging

NSAID: non-steroidal anti-inflammatory drugs

ONPK: osteonecrosis in the postoperative knee

PEMF: pulsed electromagnetic fields

PRISMA: Preferred Reporting Items for Systematic Review and Meta-analysis

RWB: restricted weight-bearing

SFK: subchondral fractures of the knee

SIFK: subchondral insufficiency fractures of the knee

SONK: spontaneous osteonecrosis of the knee

\section{Declarations}

\section{Ethics approval and consent to participate}

Not applicable

\section{Consent for publication}

Not applicable

\section{Availability of data and materials}

All data generated or analyzed during this study are included in this published article.

\section{Competing interests}

The authors declare that they have no competing interests.

\section{Funding}

No funding was received in support of this study.

\section{Authors' contributions}

$\mathrm{JL}$ was responsible for the conception and design of the manuscript as well as the acquisition, analysis and interpretation of data. JL drafted and revised the manuscript. RC was responsible for the conception and design of the manuscript, as well as the acquisition and analysis of data. RC reviewed and revised the 
manuscript. CF was responsible for data interpretation as well as review and revision of the manuscript. All authors have read and approved the submitted manuscript.

\section{Acknowledgements}

Not applicable

\section{References}

1. Ahlbäck S, Bauer GC, Bohne WH. Spontaneous osteonecrosis of the knee. Arthritis Rheum. 1968; 11(6):705-33.

2. al-Rowaih A, Björkengren A, Egund N, Lindstrand A, Wingstrand H, Thorngren KG. Size of osteonecrosis of the knee. Clin Orthop Relat Res. 1993; (287):6875 .

3. Karim AR, Cherian JJ, Jauregui JJ, Pierce T, Mont MA. Osteonecrosis of the knee: review. Ann Transl Med. 2015; 3(1):6.

4. Patel DV, Breazeale NM, Behr CT, Warren RF, Wickiewicz TL, O’Brien SJ. Osteonecrosis of the knee: current clinical concepts. Knee Surg Sports Traumatol Arthrosc. 1998; 6(1):2-11.

5. Hussain ZB, Chahla J, Mandelbaum BR, Gomoll AH, LaPrade RF. The Role of Meniscal Tears in Spontaneous Osteonecrosis of the Knee: A Systematic Review of Suspected Etiology and a Call to Revisit Nomenclature. Am J Sports Med. 2019; 47(2):501-7.

6. Mont MA, Marker DR, Zywiel MG, Carrino JA. Osteonecrosis of the knee and related conditions. J Am Acad Orthop Surg. 2011; 19(8):482-94.

7. Yates PJ, Calder JD, Stranks GJ, Conn KS, Peppercorn D, Thomas NP. Early MRI diagnosis and non-surgical management of spontaneous osteonecrosis of the knee. Knee. 2007; 14(2):112-6.

8. Moher D, Liberati A, Tetzlaff J, Altman DG, PRISMA Group. Preferred reporting items for systematic reviews and meta-analyses: the PRISMA statement. Int J Surg. 2010; 8(5):336-41.

9. Oxford Centre for Evidence-based Medicine: Levels of Evidence (March 2009). Centre for Evidence-Based Medicine. 2009

https://www.cebm.ox.ac.uk/resources/levels-of-evidence/oxford-centre-for-evidence-based-medicine-levels-of-evidence-march-2009. Accessed 2 Feb 2021.

10. Koshino T, Okamoto R, Takamura K, Tsuchiya K. Arthroscopy in spontaneous osteonecrosis of the knee. Orthop Clin North Am. 1979; 10(3):609-18.

11. Aglietti P, Insall JN, Buzzi R, Deschamps G. Idiopathic osteonecrosis of the knee. Aetiology, prognosis and treatment. J Bone Joint Surg Br. 1983; 65(5):588-97.

12. Soucacos PN, Xenakis TH, Beris AE, Soucacos PK, Georgoulis A. Idiopathic osteonecrosis of the medial femoral condyle. Classification and treatment. Clin Orthop Relat Res. 1997; (341):82-9.

13. Banzer W, Hübscher M, Schikora D. Laser-needle therapy for spontaneous osteonecrosis of the knee. Photomed Laser Surg. 2008; 26(4):301-6.

14. Fujita S, Arai Y, Honjo K, Nakagawa S, Kubo T. A Case of Spontaneous Osteonecrosis of the Knee with Early and Simultaneous Involvement of the Medial Femoral Condyle and Medial Tibial Plateau. Case Rep Orthop. 2016; doi:10.1155/2016/2574975.

15. Marti CB, Rodriguez M, Zanetti M, Romero J. Spontaneous osteonecrosis of the medial compartment of the knee: a MRI follow-up after conservative and operative treatment, preliminary results. Knee Surg Sports Traumatol Arthrosc. 2000; 8(2):83-8.

16. Pape D, Seil R, Fritsch E, Rupp S, Kohn D. Prevalence of spontaneous osteonecrosis of the medial femoral condyle in elderly patients. Knee Surg Sports Traumatol Arthrosc. 2002; 10(4):233-40.

17. Nakayama H, Iseki T, Kanto R, Daimon T, Kashiwa K, Yoshiya S. Analysis of risk factors for poor prognosis in conservatively managed early-stage spontaneous osteonecrosis of the knee. Knee. 2016; 23(1):25-8.

18. Horikawa A, Miyakoshi N, Shimada Y, Kodama H. Spontaneous Osteonecrosis of the Knee: A Retrospective Analysis by Using MRI and DEXA. Open Orthop J. 2016; 10:532-8.

19. Akamatsu Y, Kobayashi H, Kusayama Y, Aratake M, Kumagai K, Saito T. Predictive factors for the progression of spontaneous osteonecrosis of the knee. Knee Surg Sports Traumatol Arthrosc. 2017; 25(2):477-84.

20. Vaishya R, Vijay V, Vaish A. Spontaneous osteonecrosis of the knee: an unusual cause of knee pain. BMJ Case Rep. 2014; doi:10.1136/bcr-2014-204570.

21. Bittner J, Hartstein A. Spontaneous Osteonecrosis of the Knee. J Orthop Sports Phys Ther. 2018; doi:10.2519/jospt.2018.7923.

22. Horikawa A, Miyakoshi N, Hongo M, Kasukawa Y, Shimada Y, Kodama H, Sano A. Treatment of spontaneous osteonecrosis of the knee by daily teriparatide: A report of 3 cases. Medicine (Baltimore). 2020; doi:10.1097/MD.0000000000018989.

23. Meier C, Kraenzlin C, Friederich NF, Wischer T, Grize L, Meier CR, et al. Effect of ibandronate on spontaneous osteonecrosis of the knee: a randomized, double-blind, placebo-controlled trial. Osteoporos Int. 2014; 25(1):359-66.

24. Pareek A, Parkes CW, Bernard C, Camp CL, Saris DBF, Stuart MJ, Krych AJ. Spontaneous Osteonecrosis/Subchondral Insufficiency Fractures of the Knee: High Rates of Conversion to Surgical Treatment and Arthroplasty. J Bone Joint Surg Am. 2020; 102(9):821-9.

25. Bhatnagar N, Sharma S, Gautam VK, Kumar A, Tiwari A. Characteristics, management, and outcomes of spontaneous osteonecrosis of the knee in Indian population. Int Orthop. 2018; 42(7):1499-508.

26. Marcheggiani Muccioli GM, Grassi A, Setti S, Filardo G, Zambelli L, Bonanzinga T, et al. Conservative treatment of spontaneous osteonecrosis of the knee in the early stage: pulsed electromagnetic fields therapy. Eur J Radiol. 2013; 82(3):530-7. 
27. Jordan RW, Aparajit P, Docker C, Udeshi U, El-Shazly M. The importance of early diagnosis in spontaneous osteonecrosis of the knee - A case series with six year follow-up. Knee. 2016; 23(4):702-7.

28. Barroso GC, Fuchs T, Thiele E, Lima MN. Spontaneous osteonecrosis in an athlete's knee treated using a hyperbaric chamber: case report and review of the literature. Rev Bras Ortop. 2015; 47(3):389-93.

29. Geijer M, Jureus J, Hanni M, Shalabi A. MR appearance of the temporal evolution and resolution of spontaneous osteonecrosis of the knee: a case report. Acta Radiol Open. 2017; doi:10.1177/2058460116688719.

30. Breer S, Oheim R, Krause M, Marshall RP, Amling M, Barvencik F. Spontaneous osteonecrosis of the knee (SONK). Knee Surg Sports Traumatol Arthrosc. 2013; 21(2):340-5.

31. Jureus J, Lindstrand A, Geijer M, Roberts D, Tägil M. Treatment of spontaneous osteonecrosis of the knee (SPONK) by a bisphosphonate. Acta Orthop. 2012; 83(5):511-4

32. Atoun E, Mor A, Segal G, Debi R, Grinberg D, Benedict Y, et al. A non-invasive, home-based biomechanical therapy for patients with spontaneous osteonecrosis of the knee. J Orthop Surg Res. 2016;11(1):139.

33. Agarwala S, Sharoff L, Jagani N. Effect of Zoledronic Acid and Alendronate on Bone Edema and Pain in Spontaneous Osteonecrosis of the Knee: A New Paradigm in the Medical Management. Rev Bras Ortop (Sao Paulo). 2020; doi:10.1016/j.rboe.2017.12.008.

34. Lecouvet FE, Malghem J, Maldague BE, Vande Berg BC. MR imaging of epiphyseal lesions of the knee: current concepts, challenges, and controversies. Radiol Clin North Am. 2005; 43(4):655-72.

35. Akamatsu Y, Mitsugi N, Hayashi T, Kobayashi H, Saito T. Low bone mineral density is associated with the onset of spontaneous osteonecrosis of the knee. Acta Orthop. 2012; 83(3):249-55.

36. Houpt JB, Pritzker KP, Alpert B, Greyson ND, Gross AE. Natural history of spontaneous osteonecrosis of the knee (SONK): a review. Semin Arthritis Rheum. 1983; 13(2):212-27.

37. Zywiel MG, McGrath MS, Seyler TM, Marker DR, Bonutti PM, Mont MA. Osteonecrosis of the knee: a review of three disorders. Orthop Clin North Am. 2009; 40(2):193-211.

38. Zanetti M, Romero J, Dambacher MA, Hodler J. Osteonecrosis diagnosed on MR images of the knee. Relationship to reduced bone mineral density determined by high resolution peripheral quantitative CT. Acta Radiol. 2003; 44(5):525-31.

39. Pape D, Seil R, Kohn D, Schneider G. Imaging of early stages of osteonecrosis of the knee. Orthop Clin North Am. 2004; 35(3):293-303.

\section{Tables}

Table 1 Studies on the conventional forms of restricted weight-bearing (RWB) 


\begin{tabular}{|c|c|c|c|c|c|c|c|c|c|}
\hline Study & $\begin{array}{l}\text { Level of } \\
\text { evidence }\end{array}$ & $\begin{array}{l}\text { No. of } \\
\text { patients }\end{array}$ & Therapy & Additional therapy & $\begin{array}{l}\text { Therapy } \\
\text { duration } \\
\text { in months }\end{array}$ & $\begin{array}{l}\text { Mean } \\
\text { follow- } \\
\text { up in } \\
\text { months }\end{array}$ & $\begin{array}{l}\text { No. of condyles } \\
\text { affected: } \\
\text { MFC/LFC/MTP/LTP/MI }\end{array}$ & $\begin{array}{l}\text { No. of knees } \\
\text { in } \\
\text { Koshino } \\
\text { Stage: } \\
1 / 2 / 3 / 4\end{array}$ & $\begin{array}{l}\text { Mean lesion s } \\
\text { (MRI) }\end{array}$ \\
\hline $\begin{array}{l}\text { Marti et } \\
\text { al. [15] }\end{array}$ & $2 b$ & 4 & RWB & NSAID & 3 & 14.5 & $\begin{array}{l}\text { 3/0/1/0/0 (Affection of } \\
\text { medial compartment } \\
\text { was inclusion criterion!) }\end{array}$ & $2 / 1 / 0 / 1$ & $\begin{array}{l}\text { Necrosis/ BM } \\
\text { coronal MRl: } \\
0.67 / 1.37 \mathrm{~cm}^{2}\end{array}$ \\
\hline $\begin{array}{l}\text { Pape et } \\
\text { al. [16] }\end{array}$ & $2 \mathrm{~b}$ & 6 & Crutches & NSAID + Exercise & $\begin{array}{l}\text { Minimum } \\
\text { of } 1.5\end{array}$ & 12 & $\mathrm{x}$ & $6 / 0 / 0 / 0$ & $\mathrm{x}$ \\
\hline $\begin{array}{l}\text { Yates et } \\
\text { al. [7] }\end{array}$ & 4 & $\begin{array}{l}14(20 \\
\text { knees) }\end{array}$ & RWB & NSAID & $\begin{array}{l}4.8 \text { (mean } \\
\text { treatment } \\
\text { duration, } \\
\text { treatment } \\
\text { until pain } \\
\text { subsided) }\end{array}$ & 8 & $\begin{array}{l}x / 9 / x / x / 6 \text { (not clearly } \\
\text { defined) }\end{array}$ & $20 / 0 / 0 / 0$ & Kerboul angle \\
\hline $\begin{array}{l}\text { Jordan et } \\
\text { al. [27] }\end{array}$ & 4 & $\begin{array}{l}37(40 \\
\text { knees) }\end{array}$ & RWB & $x$ & 1.5 & 72 & $21 / 6 / 11 / 0 / 2$ & $x$ & $13 \times 15.8 \times 6$ \\
\hline $\begin{array}{l}\text { Fujita et } \\
\text { al. [14] }\end{array}$ & 5 & 1 & RWB & NSAID + Hyaluronan & 6 (probably) & 36 & 0/0/0/0/1 & $0 / 0 / 1 / 0$ & $\mathrm{x}$ \\
\hline $\begin{array}{l}\text { Horikawa } \\
\text { et al. [18] }\end{array}$ & $2 b$ & 20 & Bed rest & NSAID & 1 & 1 & $20 / 0 / 0 / 0 / 0$ & $x$ & $\begin{array}{l}\text { High/low inte } \\
\text { area }\left(\mathrm{mm}^{2}\right) \text { o } \\
\text { coronal T2: } 7 \\
\text { (conservative } \\
\text { versus 47.7/1 } \\
\text { (UKA) }\end{array}$ \\
\hline $\begin{array}{l}\text { Akamatsu } \\
\text { et al. [19] }\end{array}$ & $2 b$ & 54 & RWB & NSAID & $x$ & 12 & $54 / 0 / 0 / 0 / 0$ & $\begin{array}{l}\text { Conservative: } \\
\text { 10/15/2/0 } \\
\text { Operative: } \\
\text { 4/20/3/0 }\end{array}$ & $\begin{array}{l}\text { Conservative: } \\
11.8 \times 18.7 \times \\
\text { Operative: } \\
13.9 \times 24.2 \times\end{array}$ \\
\hline $\begin{array}{l}\text { Bittner et } \\
\text { al. [21] }\end{array}$ & 5 & 1 & RWB & $\mathrm{x}$ & 1 & 1 & $1 / 0 / 0 / 0 / 0$ & $0 / 0 / 1 / 0$ & $\mathrm{x}$ \\
\hline
\end{tabular}

Abbreviations: bone marrow edema (BME), lateral femoral condyle (LFC), lateral tibial plateau (LTP), magnetic resonance imaging (MRI), medial femoral condyle (MFC), medial tibial plateau (MTP) multiple involvement (MI), no data found ( $x$ ), non-steroidal anti-inflammatory drugs (NSAID), unicompartmental knee arthroplasty (UKA)

Table 2 Studies on special devices for restricted weight-bearing (RWB) 


\begin{tabular}{|c|c|c|c|c|c|c|c|c|c|c|}
\hline Study & $\begin{array}{l}\text { Level of } \\
\text { evidence }\end{array}$ & $\begin{array}{l}\text { No. of } \\
\text { patients }\end{array}$ & Therapy & $\begin{array}{l}\text { Additional } \\
\text { therapy }\end{array}$ & $\begin{array}{l}\text { Therapy } \\
\text { duration } \\
\text { in } \\
\text { months }\end{array}$ & $\begin{array}{l}\text { Mean } \\
\text { follow- } \\
\text { up in } \\
\text { months }\end{array}$ & $\begin{array}{l}\text { No. of condyles } \\
\text { affected: } \\
\text { MFC/LFC/MTP/LTP/MI }\end{array}$ & $\begin{array}{l}\text { No. of } \\
\text { knees in } \\
\text { Koshino } \\
\text { Stage: } \\
\text { 1/2/3/4 }\end{array}$ & $\begin{array}{l}\text { Mean } \\
\text { lesion } \\
\text { size } \\
\text { (MRI) }\end{array}$ & Outcome \\
\hline $\begin{array}{l}\text { Nakayama } \\
\text { et al. [17] }\end{array}$ & 4 & $\begin{array}{l}36(38 \\
\text { knees) }\end{array}$ & $\begin{array}{l}\text { Lateral wedge } \\
\text { insole + cane }\end{array}$ & $\begin{array}{l}\text { Exercize + } \\
\text { Hyaluronan + } \\
\text { NSAID }\end{array}$ & $x$ & $\begin{array}{l}34.9 \pm \\
14.1\end{array}$ & $38 / 0 / 0 / 0 / 0$ & $\begin{array}{l}\text { All in } \\
\text { stage } 1 \\
\text { or } 2\end{array}$ & $x$ & $\begin{array}{l}\text { Clinical } \\
\text { improvem } \\
\text { in } 71.0 \% \text {. } \\
\text { Radiologic } \\
\text { worsening } \\
21.1 \%\end{array}$ \\
\hline $\begin{array}{l}\text { Atoun et } \\
\text { al. [32] }\end{array}$ & 4 & 17 & $\begin{array}{l}\text { Shoes } \\
\text { (AposTherapy) } \\
\text { up to } 60 \text { min } \\
\text { daily }\end{array}$ & $x$ & 6 & 6 & $x$ & $x$ & $x$ & $\begin{array}{l}\text { Improveme } \\
\text { in most of } \\
\text { the } \\
\text { measured } \\
\text { gait } \\
\text { parameter: } \\
\text { pain, } \\
\text { function, a } \\
\text { QoL }\end{array}$ \\
\hline $\begin{array}{l}\text { Pareek et } \\
\text { al. [24] }\end{array}$ & $2 b$ & 223 & $\begin{array}{l}84 \% \text { RWB/ } \\
78 \% \text { unloader } \\
\text { braces }\end{array}$ & $\begin{array}{l}\text { Hyaluronan }+ \\
\text { corticosteroids }\end{array}$ & $x$ & 52.8 & $129 / 17 / 107 / 12 / 51$ & $x$ & $x$ & $\begin{array}{l}\text { Persistenc } \\
\text { of } \\
\text { symptoms } \\
\text { surgery } \\
\text { required in } \\
47 \% \text { of } \\
\text { patients }\end{array}$ \\
\hline
\end{tabular}

Abbreviations: lateral femoral condyle (LFC), lateral tibial plateau (LTP), magnetic resonance imaging (MRI), medial femoral condyle (MFC), medial tibial plateau (MTP) multiple involvement (MI), no data found (X), non-steroidal anti-inflammatory drugs (NSAID), Quality of Life (QoL)

Table 3 Studies on bisphosphonates

\begin{tabular}{|c|c|c|c|c|c|c|c|c|c|c|}
\hline Study & $\begin{array}{l}\text { Level of } \\
\text { evidence }\end{array}$ & $\begin{array}{l}\text { No. of } \\
\text { patients }\end{array}$ & Therapy & Additional therapy & $\begin{array}{l}\text { Therapy } \\
\text { duration } \\
\text { in } \\
\text { months }\end{array}$ & $\begin{array}{l}\text { Mean } \\
\text { follow- } \\
\text { up in } \\
\text { months }\end{array}$ & $\begin{array}{l}\text { No. of condyles } \\
\text { affected: } \\
\text { MFC/LFC/MTP/LTP/MI }\end{array}$ & $\begin{array}{l}\text { No. of } \\
\text { knees } \\
\text { in } \\
\text { Stage: } \\
1 / 2 / 3 / 4\end{array}$ & $\begin{array}{l}\text { Mean } \\
\text { lesion } \\
\text { size } \\
(\mathrm{MRI})\end{array}$ & Outcome \\
\hline $\begin{array}{l}\text { Breer } \\
\text { et al. } \\
\text { [30] }\end{array}$ & 4 & 5 & $\begin{array}{l}\text { lbandronate } \\
3 \mathrm{mg} \text { iv in } \\
\text { interval of } 2 \\
\text { months }\end{array}$ & $\begin{array}{l}\text { Vitamin D (until } \\
\text { normal level, then } \\
\text { ibandronate) }\end{array}$ & 2 & 4 & $5 / 0 / 0 / 0 / 0$ & $5 / 0 / 0 / 0$ & $17.5 \mathrm{~cm}^{2}$ & $\begin{array}{l}\text { Improvem } \\
\text { of } \\
\text { symptoms } \\
\text { and full } \\
\text { remission c } \\
\text { the } \\
\text { pathologic } \\
\text { MRI }\end{array}$ \\
\hline $\begin{array}{l}\text { Jureus } \\
\text { et al. } \\
\text { [31] }\end{array}$ & 4 & 17 & $\begin{array}{l}\text { Alendronate } \\
70 \mathrm{mg} \mathrm{po} \\
\text { weekly }\end{array}$ & $x$ & 11 & $12-48$ & $14 / 3 / 0 / 0 / 0$ & $7 / x / x / x$ & $\begin{array}{l}\text { Lotke } \\
\text { index: } \\
30.6 \%\end{array}$ & $\begin{array}{l}\text { Prevention } \\
\text { of articular } \\
\text { collapse in } \\
82.4 \% \text { of } \\
\text { cases }\end{array}$ \\
\hline $\begin{array}{l}\text { Meier } \\
\text { et al. } \\
\text { [23] }\end{array}$ & $2 b$ & 30 & $\begin{array}{l}\text { lbandronate } \\
1.5-3 \mathrm{mg} \text { iv, } \\
10.5 \mathrm{mg} \\
\text { within } 2 \\
\text { weeks }+ \\
3 \mathrm{mg} \text { after } 3 \\
\text { months }\end{array}$ & $\begin{array}{l}\text { Vitamin } \\
\text { D + Calcium } \\
\text { carbonate + NSAID }\end{array}$ & 3 & 12 & Only MFC and LFC & $x$ & $x$ & $\begin{array}{l}\text { Reduction } \\
\text { radiologica } \\
\text { signs and } \\
\text { symptoms, } \\
\text { but no } \\
\text { significant } \\
\text { difference } \\
\text { placebo }\end{array}$ \\
\hline
\end{tabular}

Abbreviations: lateral femoral condyle (LFC), lateral tibial plateau (LTP), magnetic resonance imaging (MRI), medial femoral condyle (MFC), medial tibial plateau (MTP) multiple involvement (MI), no data found (X), non-steroidal anti-inflammatory drugs (NSAID)

Table 4 Studies on bisphosphonates combined with conventional restricted weight-bearing (RWB). 


\begin{tabular}{|c|c|c|c|c|c|c|c|c|}
\hline Study & $\begin{array}{l}\text { Level of } \\
\text { evidence }\end{array}$ & $\begin{array}{l}\text { No. of } \\
\text { patients }\end{array}$ & Therapy & Additional therapy & $\begin{array}{l}\text { Therapy } \\
\text { duration in } \\
\text { months }\end{array}$ & $\begin{array}{l}\text { Mean } \\
\text { follow- } \\
\text { up in } \\
\text { months }\end{array}$ & $\begin{array}{l}\text { No. of condyles } \\
\text { affected: } \\
\text { MFC/LFC/MTP/LTP/MI }\end{array}$ & $\begin{array}{l}\text { No. of knees } \\
\text { in Koshino } \\
\text { Stage: } \\
1 / 2 / 3 / 4\end{array}$ \\
\hline $\begin{array}{l}\text { Vaishya et } \\
\text { al. [20] }\end{array}$ & 5 & 1 & $\begin{array}{l}\text { Crutches + } \\
\text { alendronate } \\
70 \mathrm{mg} \text { po } \\
\text { weekly }\end{array}$ & NSAID & $\begin{array}{l}\text { Crutches: } 2 \\
\text { Alendronate: } \\
2\end{array}$ & 2 & $1 / 0 / 0 / 0 / 0$ & $1 / 0 / 0 / 0$ \\
\hline $\begin{array}{l}\text { Geijer et } \\
\text { al. [29] }\end{array}$ & 5 & 1 & $\begin{array}{l}\text { RWB + } \\
\text { alendronate } \\
70 \mathrm{mg} \text { po } \\
\text { weekly for } 5 \\
\text { months, then } \\
\text { zoledronate } \\
5 \mathrm{mg} \text { iv in } \\
\text { interval of } 6 \\
\text { months. }\end{array}$ & NSAID & $\begin{array}{l}\text { RWB: at } \\
\text { least } 12 \\
\text { Alendronate: } \\
5 \\
\text { Zoledronate: } \\
13\end{array}$ & 30 & $1 / 0 / 0 / 0 / 0$ & $\begin{array}{l}1 / 0 / 0 / 0 \\
\text { (Progression } \\
\text { to stage 2) }\end{array}$ \\
\hline $\begin{array}{l}\text { Bhatnagar } \\
\text { et al. [25] }\end{array}$ & 4 & 10 & $\begin{array}{l}\text { Crutches/cane } \\
\text { + ibandronate } \\
150 \mathrm{mg} \text { po } \\
\text { monthly }\end{array}$ & NSAID/analgesics + Exercise & $\begin{array}{l}\text { Crutches: } \\
1.5 \\
\text { Walking } \\
\text { stick: } 1.5 \\
\text { lbandronate: } \\
12\end{array}$ & 12 & $8 / 1 / 1 / 0 / 0$ & $7 / 3 / 0 / 0$ \\
\hline $\begin{array}{l}\text { Agarwala } \\
\text { et al. [33] }\end{array}$ & 4 & 11 & $\begin{array}{l}\text { Walker }+ \\
\text { zoledronate } \\
5 \mathrm{mg} \text { iv } 1 \mathrm{x}+ \\
\text { alendronate } \\
70 \mathrm{mg} \text { po } \\
\text { weekly }\end{array}$ & $\begin{array}{l}\text { NSAID + Calcium + Vitamin } \\
\text { D }\end{array}$ & $\begin{array}{l}\text { Walker: } 3 \\
\text { Zoledronate: } \\
\text { single dose } \\
\text { Alendronate: } \\
4\end{array}$ & 4 & $10 / 1 / 0 / 0 / 0$ & $x$ \\
\hline
\end{tabular}

Abbreviations: bone marrow lesion (BML), lateral femoral condyle (LFC), lateral tibial plateau (LTP), magnetic resonance imaging (MRI), medial femoral condyle (MFC), medial tibial plateau (MTP) multiple involvement (MI), no data found ( $x$ ), non-steroidal anti-inflammatory drugs (NSAID)

Table 5 Studies on further treatment concepts

\begin{tabular}{|c|c|c|c|c|c|c|c|c|c|c|}
\hline Study & $\begin{array}{l}\text { Level of } \\
\text { evidence }\end{array}$ & $\begin{array}{l}\text { No. of } \\
\text { patients }\end{array}$ & Therapy & $\begin{array}{l}\text { Additional } \\
\text { therapy }\end{array}$ & $\begin{array}{l}\text { Therapy } \\
\text { duration } \\
\text { in } \\
\text { months }\end{array}$ & $\begin{array}{l}\text { Mean } \\
\text { follow- } \\
\text { up in } \\
\text { months }\end{array}$ & $\begin{array}{l}\text { No. of condyles } \\
\text { affected: } \\
\text { MFC/LFC/MTP/LTP/MI }\end{array}$ & $\begin{array}{l}\text { No. of } \\
\text { knees in } \\
\text { Koshino } \\
\text { Stage: } \\
\text { 1/2/3/4 }\end{array}$ & $\begin{array}{l}\text { Mean } \\
\text { lesion size } \\
\text { (MRI) }\end{array}$ & Out \\
\hline $\begin{array}{l}\text { Banzer et al. } \\
\text { [13] }\end{array}$ & 5 & 1 & $\begin{array}{l}\text { Laser-needle } \\
\text { therapy for } 1 \\
\text { hour daily }\end{array}$ & $x$ & 3 & 8.75 & $1 / 0 / 0 / 0 / 0$ & $x$ & $x$ & $\begin{array}{l}\text { Full } \\
\text { of } \\
\text { syn } \\
\text { anc } \\
\text { pat } \\
\text { MR }\end{array}$ \\
\hline $\begin{array}{l}\text { Marcheggiani } \\
\text { Muccioli et } \\
\text { al. [26] }\end{array}$ & 4 & 28 & $\begin{array}{l}\text { PEMF for } 6 \\
\text { hours daily }\end{array}$ & NSAID & 3 & 24 & $x$ & $28 / 0 / 0 / 0$ & $x$ & $\begin{array}{l}\text { Pai } \\
\text { redı } \\
75 \% \\
\text { WO } \\
\text { dec } \\
85 .\end{array}$ \\
\hline $\begin{array}{l}\text { Barroso et al. } \\
{[28]}\end{array}$ & 5 & 1 & $\begin{array}{l}\text { Hyperbaric } \\
\text { chamber } 10 x \\
+ \\
\text { ibandronate } \\
\text { po + RWB }\end{array}$ & $\begin{array}{l}\text { Exercise, } \\
\text { cryotherapy, } \\
\text { ultrasound, } \\
\text { acupuncture, } \\
\text { calcitonin, } \\
\text { calcium } \\
\text { carbonate, } \\
\text { cholecalciferol }\end{array}$ & $x$ & 3.6 & $1 / 0 / 0 / 0 / 0$ & $1 / 0 / 0 / 0$ & $x$ & $\begin{array}{l}\text { Sig } \\
\text { clin } \\
\text { imf }\end{array}$ \\
\hline $\begin{array}{l}\text { Horikawa et } \\
\text { al. [22] }\end{array}$ & 4 & 3 & $\begin{array}{l}\text { Teriparatide } \\
20 \mu g \text { sc } \\
\text { daily }\end{array}$ & $x$ & $x$ & 10 & $x$ & $3 / 0 / 0 / 0$ & $\begin{array}{l}\text { High/low } \\
\text { intensity } \\
\text { area } \\
\left(\mathrm{mm}^{2}\right) \text { on } \\
\text { T2: } \\
69.2 / 237.6\end{array}$ & $\begin{array}{l}\operatorname{Imp} \\
\text { of } \\
\text { syn } \\
\text { anc } \\
\text { pat } \\
\text { MR }\end{array}$ \\
\hline
\end{tabular}

Abbreviations: lateral femoral condyle (LFC), lateral tibial plateau (LTP), magnetic resonance imaging (MRI), medial femoral condyle (MFC), medial tibial plateau (MTP) multiple involvement (MI), no data found (X), non-steroidal anti-inflammatory drugs (NSAID), pulsed electromagnetic fields (PEMF), whole-organ magnetic resonance imaging score (WORMS) 
Table 6 Treatment recommendations in dependency of presentation in magnetic resonance imaging (MRI)

\begin{tabular}{|c|c|c|c|}
\hline MRI feature & Therapy & GOR & Conflicting studies \\
\hline BME & $\begin{array}{l}\text { Conventional RWB } \\
\text { Bisphosphonates } \\
\text { Conventional RWB and bisphosphonates } \\
\text { PEMF therapy } \\
\text { Teriparatide }\end{array}$ & $\begin{array}{l}\text { B }[16,27] \\
\text { C }[30] \\
\text { C }[25,33] \\
\text { C }[26] \\
\text { D }[22]\end{array}$ & $\begin{array}{l}x \\
x \\
x \\
x \\
x\end{array}$ \\
\hline BME as concomitant lesion & $\begin{array}{l}\text { Conventional RWB } \\
\text { Conventional RWB and bisphosphonates } \\
\text { Teriparatide }\end{array}$ & $\begin{array}{l}C[7,14,15] \\
\text { D }[29] \\
\text { C }[22]\end{array}$ & $\begin{array}{l}x \\
x \\
x\end{array}$ \\
\hline Fracture & $\begin{array}{l}\text { Conventional RWB } \\
\text { Bisphosphonates } \\
\text { Conventional RWB and bisphosphonates } \\
\text { Conventional RWB and bisphosphonates + hyperbaric chamber } \\
\text { Laser-needle therapy }\end{array}$ & $\begin{array}{l}D[21] \\
D[31] \\
D[20,29] \\
D[28]\end{array}$ & $\begin{array}{l}\text { Fujita et al. [14] } \\
x \\
x \\
x \\
x\end{array}$ \\
\hline Cyst & Conventional RWB and bisphosphonates & C $[25,29,33]$ & $x$ \\
\hline Focal low signal intensity on T2 & Conventional RWB & $C[7]$ & $x$ \\
\hline $\begin{array}{l}\text { At least one of the following: } \\
\text { 1) Focal low signal intensity on T2 } \\
\text { 2) epiphyseal contour depression } \\
\text { 3) linear low signal intensities deep in condyle }\end{array}$ & Lateral wedge insoles & C [17] & $x$ \\
\hline $\begin{array}{l}\text { BME and two of the following: } \\
\text { 1) Focal low signal intensity on T2 } \\
\text { 2) epiphyseal contour depression } \\
\text { 3) linear low signal intensities deep in condyle }\end{array}$ & Conventional RWB & $\mathrm{D}[7,21]$ & Pape et al. [16] \\
\hline
\end{tabular}

Abbreviations: bone marrow edema (BME), grade of recommendation (GOR), pulsed electromagnetic fields (PEMF), Conventional RWB=restricted weightbearing without evidence for effectiveness of special devices as shown in table 2.

\section{Figures}




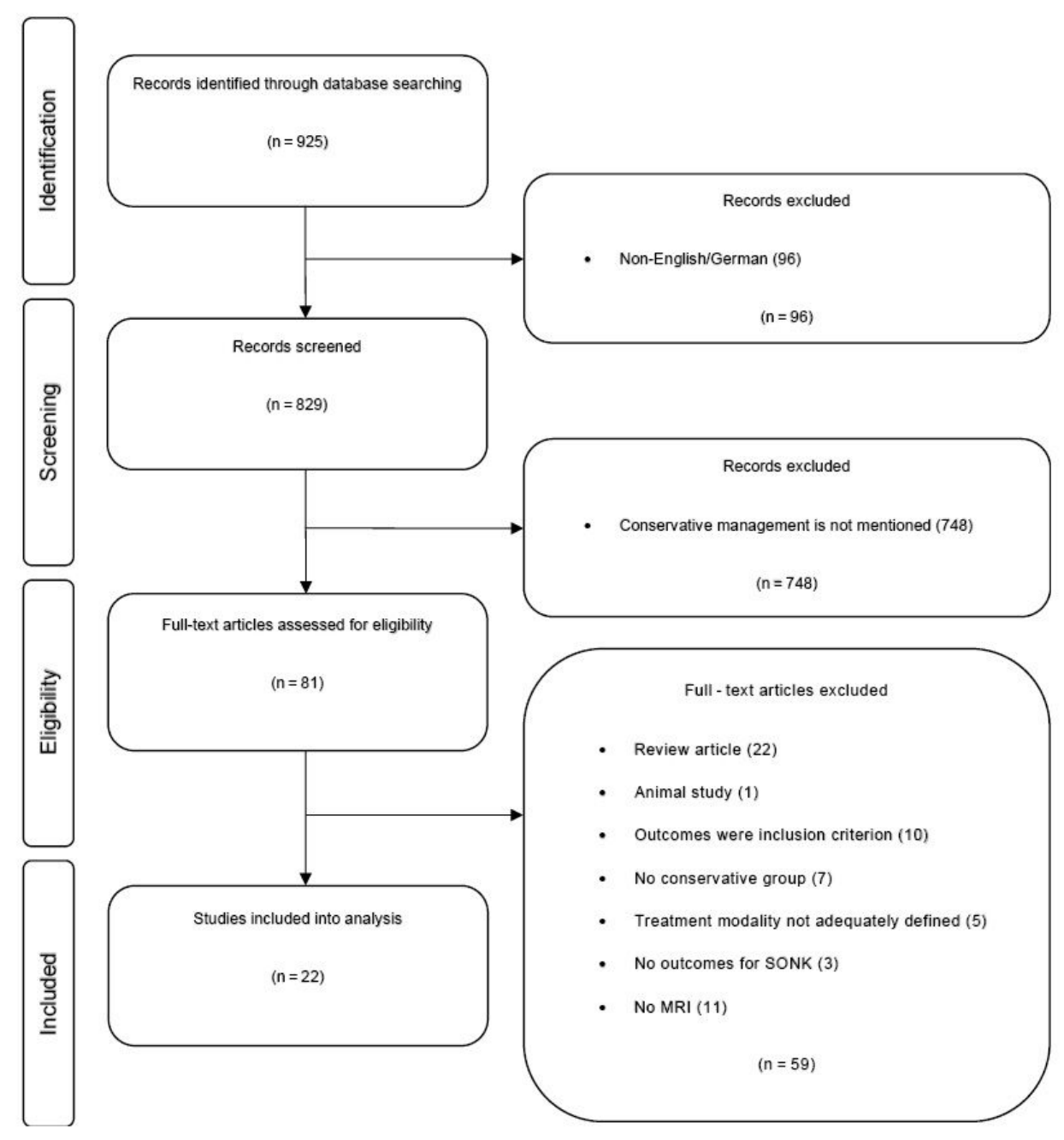

\section{Figure 1}

Flowchart reflecting the process of literature selection according to PRISMA statement [8] 